\title{
Game Theory, Tourism and Land Ethics
}

\author{
Dennis A. Kopf and Maxwell K. Hsu *
}

Marketing Department, University of Wisconsin-Whitewater, Whitewater, WI 53190, USA; kopfd@uww.edu

* Correspondence: hsum@uww.edu

\section{check for}

updates

Citation: Kopf, D.A.; Hsu, M.K. Game Theory, Tourism and Land Ethics. Sustainability 2021, 13, 8515. https://doi.org/10.3390/ su13158515

Academic Editor: Alan Fyall

Received: 8 June 2021

Accepted: 6 July 2021

Published: 30 July 2021

Publisher's Note: MDPI stays neutral with regard to jurisdictional claims in published maps and institutional affiliations.

Copyright: (c) 2021 by the authors. Licensee MDPI, Basel, Switzerland. This article is an open access article distributed under the terms and conditions of the Creative Commons Attribution (CC BY) license (https:// creativecommons.org/licenses/by/ $4.0 /)$.

\begin{abstract}
This paper combines game theory with Land Ethics to demonstrate a path forward for sustainable development. Our findings indicate that two likely equilibria can be reached. One equilibrium focuses on high short-term profits, but with ecological damage leading to less cumulative profits. The second equilibrium requires ecological maintenance costs (thus less short-term profits) yet yields greater cumulative profits. The comparison of the two equilibria and using the historical perspective of the Wisconsin Dells demonstrates how communities that embrace a Land Ethic can reach the equilibrium that produces greater long-term benefits.
\end{abstract}

Keywords: sustainable development; land ethic; ethical decision making; Wisconsin Dells; sustainable tourism; game theory

\section{Introduction}

The ease of transportation along with consumers' desires for novelty experiences facilitates the proliferation of tourism in the 21st century. However, there is often a conflict between tourism/economic development and environment protection. On one hand, tourism could provide rural employment opportunities, tax revenue, and economic diversification [1,2]. On the other hand, tourists may introduce local residents to the unwanted side effects of noise, crowdedness, and increased pollution [3]. Since tourism destinations (specifically those that feature a pristine natural environment) have strong incentives to preserve the natural environment [4], sustainable tourism has a chance to flourish through cooperation among stakeholders.

Although sustainable tourism as a percentage of tourism expenditures is growing, this segment accounts for only a small fraction of traditional mass tourism. Thus, the authors are under no illusions that the entire tourism industry will become sustainable any time soon. However, a vision for sustainable tourism development coupled with increased consumer demand for sustainable travel could make significant inroads in one of the largest sectors of the economy-tourism now accounts for over $10 \%$ of world economic activity [5].

In general, individuals are increasingly more concerned about the effect of business development activities on the environment [6]. In fact, there is evidence that sustainable and ethical consumption [7] is expanding beyond the niche market phase. From a consumer behavior perspective, research has viewed sustainable consumption through the theoretical lens of responsible consumption, anti-consumption, and mindful consumption [8].

Not only is sustainable tourism gaining in popularity among consumers, the concept of sustainable tourism governance has diffused among governments, academics, policy makers, and the tourism industry [9]. One governance concern is that as a tourism destination becomes popular and attracts too many tourists, that destination could experience deterioration in the environment due to overdevelopment, which may cause tourists to vacation elsewhere. This is especially the case when the original draw of tourists to the area was based on the pristine environment of the destination.

Dienhart [10] suggests that the unique demand of sustainability requires cross-sector collaboration. Cross-sector collaboration is when one or more organizations realize that 
they do not have the constituency, capacity, or legitimacy to carry out a mission. To accomplish the mission, organizations in different institutional sectors such as business, government, and civil society collaborate to achieve a mission. While ethics research in sustainability often looks at decision making from the perspective of one stakeholder or organization, very few examine the system of stakeholders and the cross-sector collaborations that occur to address the demands of sustainability. Dienhart [10] argues that research in cross-sector collaboration and its effect on governance that addresses issues of environmental well-being, social justice, and economic development is, at its very roots, interdisciplinary. Crane [11] echoes these sentiments by calling researchers to focus on system-level design and evaluation that maximizes benefits to all stakeholders. This approach means that "business ethics researchers will have to become more useful at working across disciplinary boundaries and partnering themselves with scholars from economics, science, engineering, psychology, sociology and various sub-disciplines of management in order to make the necessary contributions to knowledge". This research heeds this call for interdisciplinary research that has, as its unit of analysis, the interaction-sometimes cooperative and sometimes conflicting - among stakeholders, towards the goals of environmental preservation, social responsibility, and economic development. The result of this research is a game-theoretic model that has the explanatory power to aid stakeholders and policy makers to achieve transformative social, economic and environmental change.

This article is structured as follows. The article begins with a literature review. Then, the stakeholder model is developed and the implications of this model are discussed with a focus on social change. Next, a historical analysis of the Wisconsin Dells tourism industry is used to illustrate the two equilibria in the model. Finally, we conclude with a set of research propositions, directions for future research and limitations.

\section{Literature Review}

In general, economic development has been cited as a primary cause of persistent environmental problems, including widespread pollution, global warming, and environmental degradation [12,13]. As a result, the commonly held perception is that there is "an inherent, fixed trade-off: ecology versus economy" [14] (p. 120). While Porter and Van der Linde [14] posit that companies adopt a model of resource productivity may not necessarily have to face this trade-off, there still exists the question of who should bear the costs and responsibilities to maintain the environment.

Aldo Leopold's [15] idea that the land itself has rights was born out of the wanton disregard for the environment in pursuit of economic growth that he witnessed over the course of his life. His moving tribute to nature in A Sand County Almanac has found application in ethical decision making as well as influenced thought in business ethics. For example, Shrivastava et al. [16] consider land ethics to be a type of environmental virtue ethics [17] where the character or virtues of individuals necessitates that decision makers consider the rights of the environment (integrity and stability of the biotic community) in decision making. Further, Shaw [18] also uses Leopold's land ethics in reasoning that economic growth, while inevitable, must necessarily move to sustainable economic growth, given the limits to growth that our biotic community can endure.

Stakeholder theory has been applied extensively to the tourism industry. For instance, research has found that it is imperative to reduce conflict through effective cooperation among the stakeholders [19]. Stakeholder cooperation should benefit different aspects of tourism including marketing [20], planning [21], decision making and management [19], and sustainable development [22]. Through cooperation, stakeholders can avoid the cost of long-term conflict and improve their knowledge and capacity [19]. Font and Lynes [23] observed that research on corporate social responsibility in the tourism and hospitality industry focuses on the managers, employees, shareholders, and consumers as stakeholders, while communities and ecosystems as stakeholders receive very little attention. Although cooperation is ideal, perfect cooperation is not possible. In fact, there appears to be a cycle in tourism development where at first stakeholders act independently and then as they 
begin to compete for resources, the stakeholders may go through alternating stages of cooperation and conflict [24]. The links between sociodemographic characteristics and attitudes toward tourism economic sustainability were covered $[25,26]$.

Given the conflicts and opportunities for cooperation among stakeholders, it makes sense to conceptualize tourism development problems using game theory. Wei and Yan [27] used game theory to illustrate the nature of stakeholders involved in community tourism. Wei and Yan [27] find that a Pareto optimal equilibrium between stakeholders in community tourism could be reached under appropriate conditions. However, their game theoretic model only considered the objectives of profit and growth.

\section{Materials and Methods}

The main stakeholders analyzed in this model are tourism companies, local residents (community), tourists, and government policy makers. This perspective has the local residents (community) as a main stakeholder, which Font and Lynes [23] had found lacking in previous studies. The managers, owners, and employees are often viewed as separate stakeholders, but in this model, they are considered to act together in the best interest of their organization (tourism companies). According to the analysis of the interest demands of each stakeholder involved in sustainable tourism development, it appears that the game equilibrium should be reflected in the proportion of participants who choose the same strategy for improvement. There is a positive correlation in the proportion of participants who choose the same strategy and the profits gained from the choice. The higher the economic gains, the more support from local residents. However, under a reasonable allocation mechanism, the participants' personal gains depend on overall profits. That is, the game equilibrium among stakeholders of sustainable tourism development depends on the maximization of the overall profits under the requirements of ecotourism as well as a reasonable allocation mechanism.

From the sustainable tourism perspective, the ecological benefits must be given as much or more priority than economic gains. However, stakeholders may choose to pursue economic gains above the requirements of sustainability. As a result, we impose a straightforward two-alternative structure for ecotourism development:

Strategy A: The stakeholders only want to gain economic profits, without regard to the cost to maintain the ecological benefits; therefore, there are only fixed and variable costs required in ecotourism development, with no costs for ecological maintenance.

Strategy B: The stakeholders consider not only the cost for obtaining economic profit but also the cost of maintaining ecological benefits; therefore, there are fixed and variable costs required in development along with ecological maintenance costs.

\section{Results}

Appendix A shows the rationale and process by which the full economic model is developed. Specifically, the model predicts that an equilibrium exists where Strategy B will generate more profitability over the long-term than Strategy A.

This does not, however, mean that Strategy B will always be chosen. First, Strategy B does not begin to yield maximum benefits until after the critical point, $(S)$, is reached. Signs that a community is reaching the critical point $(S)$ could include the following problems: prices for locals increase, roads become congested, and aspects of the biophysical environment will show signs of harm. In particular, water quality decreases, air pollution and sound pollution from automobiles and buses increases, and tourism waste becomes difficult to manage. Soil erosion may become pronounced near nature paths and along areas of development. Flora and fauna and the pristine, natural environment that originally attracted visitors will noticeably decrease in abundance and quality. These changes will negatively affect the quality of residential life and the experience of tourists. At this point, the profit of the attraction developed by Strategy A is getting smaller and may even become a negative number. The function can be described as:

$$
L_{A}^{\prime}-L_{B}^{\prime}=L_{A}^{\prime}-L_{B}^{*}=L_{A}^{\prime}-\left(L_{A}^{*}-C_{E}\right)=C_{E}-\left(L_{A}^{*}-L_{A}^{\prime}\right)<0
$$


Since recognizing or even acknowledging that the critical point $S$ is approaching, it is unlikely that all stakeholders will come to realize that Strategy B is more appropriate than Strategy A at the same time. A very likely scenario is that residents and tourists will be the first to notice and be most affected by negative changes. Conflict of interests may occur between residents and tourists and between residents and the tourism operators.

Residents and tourists (environment protectionists) may begin to lobby the government for change. When visitors to the attraction stagnate or operators realize that the tourists are not satisfied, then tourism companies will also become concerned. Once residents, tourists, and tourism operators favor Strategy B, they can most effectively lobby the government so that the government will favor strategy $B$ as well. It may also be the case that the government may be more far-sighted or particular tourism operators may choose Strategy B before other stakeholders. No matter the order of realization, if Strategy B is to become dominant, a majority of stakeholders from all four groups must cooperate to optimize long-term benefits.

Once stakeholders favor Strategy B, cooperation will begin and attempts will be made to satisfy ecological maintenance costs. Ecological restoration projects may take place, stringent environmental regulations may be enacted and enforced, new nature preserves may be established, additional development may be approved, but only under the conditions that the tourism operators follow regulations to protect the environment. After these and other efforts meant to satisfy the ecological maintenance costs are followed, then profits of sustainable tourism associated with Strategy B are maximized. A key distinction is that for equilibrium to be achieved, all stakeholders will bear some of the costs. That is, cross-sector collaboration will take place. At this point, game equilibrium under the constraint of ecological and environmental protection is achieved.

In addition to the process by which stakeholders realize they will benefit more by following Strategy B over Strategy A, there is also the difficulty in estimating the ecological maintenance costs, $C_{E}$. The stakeholders realize that the profit gained from Strategy B is greater than the profit gained from Strategy A in the long term, but the stakeholders need to wait for an undetermined period of time to reap these additional rewards. If the difficulty in estimating ecological maintenance costs is perceived to be too great, it could discourage some stakeholders from choosing Strategy B.

\subsection{Role of Ethical Thought}

Satisfying ecological maintenance costs (Strategy B) through our game analysis is the best strategy for long-term development. Although Strategy B is the most economically favorable alternative, three prominent obstacles are preventing Strategy B: First, acknowledging that there is a critical point where profits will fall as ecological maintenance costs are neglected. Second, gaining stakeholder agreement to cooperate and choose Strategy $B$ over a reasonable time period and before any irreparable environmental damage has occurred. Third and last, estimating the ecological maintenance costs and long-term profits from ecological investments. In order to overcome these obstacles, in the second section of this paper, we detail how ethical thought and leadership, in particular the Land Ethic by Aldo Leopold can aid in overcoming these obstacles.

To illustrate the tensions between the two equilibrium over time, we chose the Wisconsin Dells, a popular tourism destination near Aldo Leopold's famous retreat immortalized in his book, A Sand County Almanac. The example provided in this article serves as a cautionary tale of a region that failed to protect the pristine and unique natural environment that made the Wisconsin Dells such an attraction in the first place. Their failure to satisfy the ecological maintenance costs for over a hundred years caused irreparable ecological damage. Indeed, the Sand County Almanac by Aldo Leopold, particularly his theory of a Land Ethic was written as a reaction to the intense market forces that led to ecological destruction (primarily through massive deforestation and poor agricultural practices during his time) of not only the area around the Wisconsin Dells, but also the Midwestern United States in general. During this time, resources of nature were assumed to be inexhaustible 
resulting in massive deforestation. In addition, irresponsible agricultural practices (leading to severe soil erosion and phosphorous contamination of water resources) and unchecked hunting proceeded without regulation or thought. In one of the most high-profile examples, the passenger pigeon-once the most abundant bird in all of North America, tragically became extinct. This was an event that was unimaginable only three decades earlier.

The development history of the Wisconsin Dells as a tourism destination is relevant to the economic model discussed above in that the Dells have experienced alternating stages of tourism development. At times during its history, the area experienced contentious and sometimes violent stakeholder conflict (usually when environmental costs were completely ignored). Meanwhile, there were other times when cooperation between stakeholders was the norm. While going through these stages, stakeholders appear to be reaching the equilibrium in our model of Strategy B. A cultural shift in the region including the widespread acceptance of a Land Ethic may have helped the shift from Strategy A to Strategy B. However, this shift happened too slowly and irreparable environmental damage had already occurred. Currently, efforts are underway to repair and improve the environmental integrity of the region but there is a chance that, in the future, the situation could digress back to a state of conflict due to some stakeholders focusing solely on profit without regard for the environment.

\subsubsection{Brief History of Wisconsin Dells}

The Dells became an ecotourism destination starting in the mid-19th century. The motivations of visitors to the Dells were similar to today's retreat-seeking tourists. During this time period, many American cities were polluted, loud, and over-crowded. In addition, advances in transportation such as railroads and steamships (and later, the automobile) made it possible for millions of city residents to escape these city conditions. Motivations for vacations to the countryside varied, but the Wisconsin Historical Society found that tourists during this time period would often seek spiritual renewal, physical regeneration, freedom from social constraints, or simply to "see the sights". Tourists sought out such places as Niagara Falls, Yellowstone, the Hudson River, and, in the Midwest, the Wisconsin Dells. Around 1849, steamship river tours allowed tourists to discover this wild and scenic place and when the railroad arrived to the Dells in 1865 (back then the Wisconsin Dells was known as Kilbourne City), it emerged as a major tourist attraction. Tourists from Midwestern industrial cities such as Chicago, Milwaukee, Cleveland, and Pittsburgh came in increasing numbers and the rapid development of hotels, parks, and other attractions made this area by far the most popular tourism destination in Wisconsin. The attraction of the place was the splendor of nature and the unique rock formations of the region. News stories and brochures about the Dells including the famous photographs of $\mathrm{HH}$ Bennett in the 1860 s and 1870 s touted the natural wonder as well as the cultural intrigue provided by Native American Indians who lived in this region. For example, the editor of the Wisconsin Mirror wrote, "We conclude that the wild, romantic scenery of the Dells will always make them a place of resort for seekers of pleasure" [26]. One hundred and sixty years later, the Wisconsin Dells now entertains over 3 million visitors annually.

\subsubsection{Cooperation Stage}

Before 1849 , only a few guides would take people up the Wisconsin River in rowboats to see the incredible rock formations. Later, steamships were able to take even more visitors on tours. Usually, these tours would stop at canyons, rock formations, and beaches for the tourists to relax, eat, and explore on foot. These activities had little impact on the environment.

After the railroad arrived, the city grew in size and soon supported a resident population of 2000. Shops, hotels, and tourism operators dominated the economy, with the notable exception that in the nearby woods, logging was taking place to support the growing demand for building materials in Chicago and raftsmen would pass through the Dells (often stopping for a night of debauchery in Kilbourne City). Despite the growth, not 
much environmental damage could be perceived by the tourists that visited the region. It was during this time period that $\mathrm{HH}$ Bennett started a thriving photography business. In 1875, he opened a shop that sold postcards of photographs that tourists could buy to bring home. Thanks to Bennett's eye for beauty, "His evocative photographs of exquisite rock formations along the Wisconsin River brought thousands of people from around the country to Wisconsin, eager to see the wonders he captured through his lens" [28]. His work appeared in national publications and within a decade, the Wisconsin Dells became the most popular tourist destination in Wisconsin [28]. Yet, there was no mention in any of the early histories of major stakeholder conflicts.

\subsubsection{Strategy A and Conflict in the Wisconsin Dells}

Conflict over differing visions of the future of the Wisconsin Dells began around 1900, when the plans for a dam on the Wisconsin River at Kilbourne City commenced. Despite HH Bennett's and raftsmen's (resident stakeholder) protests, construction was finished in 1909. The dam effectively separated the Wisconsin River into the upper and lower dells and submerged many of the famous rock formations photographed by Bennett under 15 feet of water. Residents were split on the construction of the dam, but most favored it because of the jobs and economic progress that the dam would bring to the region. Previous attempts to build the dam met with bloody conflicts and court battles between the townspeople of Kilbourne and the raftsmen that floated lumber down the river. This was the precursor for the next 75 years, characterized by a period of conflict for stakeholders. Water and nature were the primary attraction in the area, yet both decreased markedly in quality. First, half of the rock formations were now underwater and secondly, agricultural development in the region created sources of nonpoint pollution, which greatly decreased the water quality in the rivers and lakes of the region (all of the lakes in the region are now eutrophic). Development proceeded in a mostly unchecked fashion. More and more attractions were built such as water parks, amusement parks, shows, and souvenir shops. After the depression area, a huge sprawl called "the strip" was built. Houses were built up and down the river and along the newly formed Lake Delton creating new sources of pollution that further decreased water quality. Thus, the equilibrium of Strategy A seemed to be established. Rapid growth was favored and ecological maintenance costs were mostly ignored.

This trend became so evident that the Dells turned from an ecotourism destination to a place of tourism in general. Unlike before, new attractions like the thrill of the amusement parks, water parks, and shows (other than nature) were motivating people to travel to the Dells. In this way, the Dells experienced an identity crisis and many of the problems characterized in Zhao's [24] conflict stage prevailed throughout the 20th century as stakeholders had differing views of how their community should continue to be developed.

In moving away from ecotourism to simply tourism, the Dells were criticized as being artificial in the marketing literature with one scholar calling it a "polypropylene paradise" [29]. The region was now unrecognizable from HH Bennett's time. Developers morphed the Dells into something unnatural - a mini-Disneyland of the Wisconsin variety, where several mini-attraction operators such as shows, miniature golf, haunted houses, waterparks, and aging roller coasters, to even a deer park where visitors can pet "wild" deer. And although mostly a mirage, homage is paid to the old "Northwoods" character of the region with log cabin construction and the lore of Paul Bunyan-themed restaurants. Such lore is false since the area is no longer on the edge of the wilderness as it was during HH Bennett's time. To see true wilderness in Wisconsin, a person might have to travel north to the Apostle Islands near the border of Wisconsin and Canada. Even in these areas, the woods had been mostly clear-cut by logging to build the railroads west and supply lumber for the massive expansion of the cities of Chicago, Milwaukee, and Minneapolis. Rather than relying only on the draw of ecotourism, capital had been invested into a more general tourism infrastructure. The change is dramatic. 
The area currently has over 8000 hotel rooms, and 20 indoor and outdoor water parks that hold over 5 million gallons of water. Although the natural area of the Dells is no longer in pristine condition, the ecological environment is still important to visitors. And although more pure ecotourism destinations exist further north, lots of visitors to the Dells region are still looking for a connection to nature. Indeed, for some urban Chicagoans, the Dells are as close to nature as they care to venture. For example, the famous Wisconsin Ducks continue the tradition of taking tourists on a tour of the river. Nearby state parks like Mirror Lake and Devils Lake still draw large numbers of sightseers to the area. Horseback tours, hiking, cross country skiing, snowmobiling, bird watching, fishing, and almost every imaginable activity still take place in town and at the edges of town.

The next section looks at how, despite the fact that conflict and a preference for Strategy A characterized the Dells region during most of the 1900s, momentum began for Strategy B.

\subsubsection{Strategy B and Stakeholder Cooperation}

"It is inconceivable to me that an ethical relation to land can exist without love, respect, and admiration for land and a high regard for its value. By value, I of course mean something far broader than mere economic value; I mean value in the philosophical sense." [30] (p. 261)

This idea of a Land Ethic, first articulated by Aldo Leopold in 1949 was just one source of inspiration that created a wellspring of popular support for ecological preservation within the state of Wisconsin. The conservation movement in the United States became increasingly powerful as more Americans were realizing that nature's resources were threatened by industrialization [28].

Wisconsin was arguably at the center of the conservation movement. Increase Lapham was one of the first, arriving in Wisconsin in 1836. John Muir (a naturalist, writer, and the founder of the Sierra Club) grew up on a farm in Portage (in 1849), just south of the Dells and attended UW-Madison. Other notable Wisconsin conservationists were John Nolen, Charles Van Hise, and Aldo Leopold. As conservation became more of a priority, the game theory outlined above shifted to Strategy B as stakeholders recognized the need for ecological preservation in the state of Wisconsin and specifically in the vicinity of Wisconsin Dells. The residents and tourists (popular public opinion) welcomed efforts at conservation. It is difficult to pinpoint exactly when this trend towards conservation started, but a good watershed moment was when the first State Park Board (government stakeholder) was appointed in 1907.

\section{Discussion}

Economic choice does not exist in a vacuum and it is likely that many stakeholders will choose Strategy B because of the powerful influence of normative values such as Land Ethics. As the push and pull of economic growth versus sustainability continues, we theorize that many tourism destinations are likely to experience a partial loss of environmental quality as the destination becomes more popular. Once the critical juncture is reached such that the ecosystem is damaged and there is a noticeable decrease in tourism, all stakeholders are likely to see the wisdom in investing collectively in the ecosystem. This is essentially what happened in the case of the Wisconsin Dells.

The result is a boomerang effect, such that the equilibrium passes by the point where the ecosystem is damaged. As the damage is recognized, more resources are invested in preserving the ecosystem and possibly improving or repairing the damage that was done previously. Eventually, the equilibrium of Strategy B is achieved and the sustainable tourism community stays intact. However, this is the more costly route in that usually more resources are needed to repair damage than originally would have been needed for preservation. Finally, it is important to note that once some ecological resources are spoiled, it may be impossible to fix. This has happened in the Wisconsin Dells region in that water quality is likely never to return to the pristine levels when tourists first started traveling to 
the region. Furthermore, many of the most famous and beautiful rock formations are now underwater and will remain so unless the dam is removed.

\subsection{What Factors Cause Some Regions to Choose Strategy A?}

One area of future research would be to examine ecotourism areas that have failed to conserve the environment. What was the primary motivation for the various stakeholders for choosing not to maintain the ecological integrity of the attraction? Was it simply a myopic focus on profits above all else or was there a prevailing cultural attitude that nature always comes second to economic growth? Studies that examine the circumstances and consequences surrounding notable failures could be useful to policy makers and business managers in other ecotourism areas.

Furthermore, if Strategy A is chosen, the community may choose to take the capital earned in ecotourism ventures and invest that capital in ventures outside of ecotourism. A community that chooses to diversify sources of revenue may be wise to do so, but depending on what new areas of growth are pursued, this could possibly accelerate the degradation of the ecological environment [31]. For example, Jamaica is a country that often has to choose between competing industries. On the one hand, tourism (primarily beach tourism, but also ecotourism) is the main industry of Jamaica. However, in Jamaica, bauxite mining is also a major industry. These industries seem to successfully coexist at this point, yet tensions do exist, especially since foreign companies own and run the mines (and many of the resorts). These mines currently cover about $1 / 10$ th of all land in Jamaica. Future research could look at the possibility of adding another dimension to the game theoretic model where one of the actors is involved in resource extraction in a way that would greatly increase ecological maintenance costs. The mining and forestry industries are also very prominent in Wisconsin and likely in a number of other tourism areas especially in developing regions. How conflicts between competing industries are handled are worthwhile topics for future stakeholder research.

\subsection{Strategy B Chosen (Ecological Preservation)}

This two-choice game theoretic model also has implications for understanding the likelihood that successful longer-term sustainable tourism development will occur. Since, in the short term, Strategy A and B have the same effect, ethics will certainly play a role in the decision of individual stakeholders to choose one or the other. If a sufficient number of stakeholders choose to responsibly develop and maintain the tourism destination, then Strategy B becomes the default choice. They are willing to take on these extra maintenance costs simply because it seems to be the right thing to do. In this scenario, the long-term maintenance of profits occurs and the Pareto Optimality of Strategy B is achieved. In this scenario, since Strategy B was chosen not because of a rational economic choice, but was made for ethical reasons, the long-term profits can be described as an ethical dividend. As noted in the Wisconsin Dells example, ethical ideals of residents such as Increase Lapham, John Muir, H.H. Bennet, and Aldo Leopold played a role in a changing of culture within Wisconsin (and nationally) concerning humanity's relationship with nature. For example, Aldo Leopold proposes an extension of ethics to include land, water, and wildlife. His Land Ethic warns against thinking about the land solely in economic terms. The following excerpts from his classic book, A Sand County Almanac describe this ideology:

"That land is a community is the basic concept of ecology, but that land is to be loved and respected is an extension of ethics." [30] (p. xix)

"A land ethic, then, reflects the existence of an ecological conscience, and this in turn reflects a conviction of individual responsibility for the health of land." [30] (p. 258)

If stakeholders accepted Leopold's Land Ethic, then the two-choice model described in this paper would lean heavily towards the probability that Strategy B is chosen. Although, this paper finds that sustainable tourism development can make economic sense, the allure of greater short-term profits is ever-present. However, when ethics are considered as 
part of stakeholders' choices the pathway to the second equilibrium of strategy B will be more assured.

Proposition 1. If the community of stakeholders has a strong ethical perspective (such as a Land Ethic) then Strategy B is more likely to be chosen at the onset of tourism development.

Another advantage of this economic model is that the results could be generalized across differing contexts. The limitation is that this generalizability comes at the expense of oversimplification. Thus, the authors caution that the results of two equilibrium (Strategy A and Strategy B) not be used to generate precise results, but rather used to understand the rational behavior and the tendencies for stakeholders to maximize profits or utility. Despite this weakness, we can see in the case of the Wisconsin Dells that stakeholders did tend towards cooperation in the long-run and seem to favor Strategy B. However, the Wisconsin Dells example also showed the importance of culture and how changes in ethical thoughts and norms influenced the outcomes of the Wisconsin Dells from one strategy towards the other.

In terms of values, one factor that may have an important effect on whether or not a community of stakeholders chooses to maintain the environment is Hofstede's fifth dimension of national culture, long-term versus the short-term orientation [32]. This dimension was found to correlate with both the World Values Survey and the Chinese Values Survey [32]. Thus, we propose the following:

Proposition 2. Stakeholder communities with a short-term orientation (long-term orientation) are more likely to ignore (accept) environmental maintenance costs.

This proposition is logical, since according to our model the effects of ignoring ecological maintenance costs takes time to manifest in the form of reduced profits.

Besides the previous research propositions, the authors recommend that the stakeholder model be used as a guideline for understanding the process by which stakeholders cooperate in tourism destinations [33,34]. From this, a number of future studies could be conducted by which stakeholders in tourism destinations are surveyed with a goal of understanding how each of the stakeholders view the other stakeholders. From this, researchers could get an idea of levels of cooperation and ethical behaviors. This data could be compared with performance measures of both profitability and growth of the destination as well as adherence to a set of environmental standards. Such a study could prove or disprove the main conclusion of this article that cooperation must occur for a destination to thrive both economically as well as environmentally.

\section{Conclusions}

Notably, sustainability for tourism development has been addressed in the literature but no prior study has clearly illustrated this important issue using a straightforward game theory model. It is noteworthy that the direct comparison of two strategies (i.e., Strategy A vs. Strategy B) leads to a consistent findings with $\mathrm{Xu}$ and Sofield's suggestion that "a pro-active sustainability approach should be integrated with environmental concerns in the future to allow tourism to participate constructively in the national transformation to a sustainable society" [35] (p. 1). After all, maintaining a tourism destination's reputation is important for the continual growth and success of the whole tourism industry. On an international level, the authors recommend that organizations can play a role in nudging stakeholders towards the desired goal of sustainable development with our framework in mind. For example, the United Nations World Tourism Organization and international non-governmental organizations can help stakeholders better understand the ecological maintenance costs, issue best practices, and offer financial or technical support for communities that are interested in sustainable tourism development. Just helping organizations to understand ecological maintenance costs and the consequences if these costs are ignored makes it easier for communities to commit to sustainable development. In addition, these 
international organizations can continue to foster the ethos of the Land Ethic and both the intrinsic and extrinsic benefits of sustainable development. Further, environmental organizations should focus on leadership training to facilitate better stakeholder cooperation. Additionally, training on sustainable development models such as the circular economy and regenerative development $[36,37]$ hold promise to creating more successful tourism development in the future.

In addition to applying the results towards sustainable tourism outcomes, it is likely that our results can be generalized to stakeholders involved in sustainable development. For example, we illustrated the advantage of sustainable development using a regional tourism focus (Wisconsin Dells). A similar myopia (i.e., economic growth over sustainable development) may also occur at the national level. For instance, the Chinese communist government followed the "pollute first, control later" guideline when China first opened its doors to foreign investment in the 1980s, and this costly mentality was not replaced with protection of the environment by Beijing until 1993 [38]. Thus, the authors recommend applying this game theoretic model and ethical perspective in diverse areas such as public policy, business strategy, residential development, and city planning.

Author Contributions: Conceptualization, D.A.K., and M.K.H.; methodology, writing-original draft preparation, D.A.K.; writing-review and editing, D.A.K. and M.K.H. All authors have read and agreed to the published version of the manuscript.

Funding: This research received no external funding.

Institutional Review Board Statement: Not Applicable.

Informed Consent Statement: Not Applicable.

Data Availability Statement: Not Applicable.

Conflicts of Interest: The authors declare no conflict of interest.

\section{Appendix A}

Strategy A: The stakeholders only want to gain economic profits, without regard to the cost to maintain the ecological benefits; therefore, there are only fixed costs and variable costs required in ecotourism development, with no costs for ecological maintenance.

Strategy B: The stakeholders consider not only the cost for obtaining economic profit but also the cost of maintaining the ecological benefits; therefore, there are fixed costs and variable costs required in development along with ecological maintenance costs.

$F C$ can be set as fixed costs, which is a constant; $V C$ as variable costs, $V C$ is a nondecreasing function of the number of tourists $Q$, that is $V C=V C(Q), \frac{\partial V C}{\partial Q} \geq 0$ and $V C(0)=0$; set $C_{E}$ as ecological maintenance costs, and $C_{E}$ has a significant relationship with tourists' personal behavior and not the number of visitors $Q$; therefore, $C_{E}$ can be assumed to be a constant input; set $T R$ as total revenue, $T R$ is a strictly increasing function of the number of tourists $Q, T R=T R(Q), \frac{\partial T R}{\partial Q}>0$ and $T R(0)=0$.

Set $L_{A}, L_{B}, Q_{A}, Q_{B}$ respectively represent the total revenue and the number of tourists corresponding to the two strategies. Based on the above assumptions, this article can get the profit function model of each strategy:

Strategy A:

$$
L_{A}=T R\left(Q_{A}\right)-V C\left(Q_{A}\right)-F C
$$

Strategy B:

$$
L_{B}=T R\left(Q_{B}\right)-V C\left(Q_{B}\right)-F C-C_{E}
$$

If the two strategies can reach the maximum profits, for Strategy $\mathrm{A}$, the condition of the first derivative that $L_{A}$ reaches the maximum profit $L_{A}^{*}$ :

$$
\operatorname{TR}\left(Q_{A}\right)^{\prime}=V C\left(Q_{A}\right)^{\prime}
$$

and, $L_{A}=L_{A}^{*}, Q_{A}=Q_{A}^{*}$. 
For Strategy B, the condition of the first derivative that $L_{B}$ reaches the maximum profit

$$
L_{B}^{*}: T R\left(Q_{B}\right)^{\prime}=V C\left(Q_{B}\right)^{\prime}
$$

and, $L_{B}=L_{B}^{*}, Q_{B}=Q_{B}^{*}$.

When the two strategies reach the maximum profit, the following relations should be satisfied: $Q_{A}^{*}=Q_{B}^{*}, q^{*}=Q_{A}^{*}=Q_{B}^{*} ; L_{A}^{*}>L_{B}^{*}, L_{A}^{*}-L_{B}^{*}=C_{E}$.

Regardless of the chosen strategy, the number of tourists in the early stages of development would not reach a critical mass by definition. If the maximum profit can be achieved, the number of tourists will reach $q^{*}\left(q^{*}=Q_{A}^{*}=Q_{B}^{*}\right)$. When the number of tourists is less than $q^{*}$, the realized profit will be less than the maximum profit. In contrast, when the number of tourists is more than $q^{*}$, the corresponding profit will also fall short of the maximum profit due to the increased average cost and rising environmental costs. In the long term, once the number of visitors reaches $q^{*}$, the tourism attraction will maintain the number of tourists at the level $q^{*}$ as profit would have reached its maximum based on the game theory. Thus, the allowed number of tourists in the tourism attraction should not be more than $q^{*}$, in which $q^{*}$ is identified as the equilibrium value (the maximum value) number of tourists. Before $q^{*}$ is reached the situation (in the short term) corresponds to Zhao's (2003) cooperative stage.

Since this stage is characterized as a period of cooperation and not conflict, regardless of what strategy each stakeholder favors they have not reached a critical point where conflict begins. The transition from a stage of cooperation to a stage of conflict is then categorized as the critical point, $S$. Specifically, at the time before $S$, the destruction of the ecological environment has not accumulated to the extent that the destination would be abandoned by tourists, and this period can be called "short term". When it enters "long term" after $S$, the destruction of the ecological environment would become a notable issue. Once tourists learn about the destruction of the ecological environment, the number of tourists could decrease.

According to the above analysis, in the "short term", for Strategy A, the ecological destruction has not reached the extent that can be identified by the tourists, and the ecological environment of the attraction is viewed as the original (pristine) level. In contrast, for Strategy B, ecological protection costs could maintain the ecological environment to keep the original ecological level. Notably, for the tourists, there are no differences between Strategy A and B in the short term. Therefore, both Strategy A and Strategy B are likely to attract the same number of tourists, that is, $Q_{A}=Q_{B}$, and then, $T R\left(Q_{A}\right)=T R\left(Q_{B}\right)$.

It is easy to find: $L_{A}>L_{B}$ and $L_{A}-L_{B}=C_{E}$. When the critical point $S$ is reached, both strategies (A, B) could attract the maximum number of tourists in the "short term". If $q^{S}\left(q^{S} \leq q^{*}\right)$ is set as the maximum number, the profits at this point will also reach the highest profit in the short term for both Strategy A and B. It is worthy to note that $L_{A}^{S}$ and $L_{B}^{S}$ represent the corresponding profit at $S$, then $L_{A}^{S}>L_{B}^{S}, L_{A}^{S}-L_{B}^{S}, L_{A}^{S}-L_{B}^{S}=C_{E}$.

According to the pursuit of the interests of the four stakeholder groups, it is likely that Strategy A will be chosen for the short-term equilibrium. However, in the "long term" (after $S$ ), when the environmental damages caused by Strategy $A$ are identified, the number of tourists $Q_{A}$ would be less, leading to the decreasing of $T R\left(Q_{A}\right)$ and $V C\left(Q_{A}\right)$. At this period, because $Q_{A}$ is likely to become less and less, $T R\left(Q_{A}\right)$ would decrease below the short-term equilibrium value. The profit was set $L_{A}^{\prime}$ at this period, then $L_{A}^{\prime}$ was less than the short-term maximum profit $L_{A}^{S}$, that is to say, $L_{A}^{\prime}<L_{A}^{S}$. As Strategy $B$ already incorporates the costs of ecological protection, the ecological environment would remain at the initial level, so the number of tourists would increase steadily until it reaches $Q_{B}^{*}\left(Q_{B}^{*}=q^{*} \geq q^{S}\right)$. The profit was set at $L_{B}^{\prime}$ for this period, then $L_{B}^{\prime}=L_{B}^{*}$, and the situation under Strategy $B$ would maintain the maximum profit (long-term equilibrium), $L_{B}^{*}$.

Because $L_{A}^{*}-L_{B}^{*}=C_{E}, L_{A}^{\prime}<L_{A}^{S} \leq L_{A}^{*}$;

In the long run,

$$
L_{A}^{\prime}-L_{B}^{\prime}=L_{A}^{\prime}-L_{B}^{*}=L_{A}^{\prime}-\left(L_{A}^{*}-C_{E}\right)=C_{E}-\left(L_{A}^{*}-L_{A}^{\prime}\right)
$$


and, $L_{A}^{\prime}\left\langle L_{A}^{*},\left(L_{A}^{*}-L_{A}^{\prime}\right)\right\rangle 0$.

$C_{E}$ and $L_{A}^{*}$ are both constants, so $L_{A}^{\prime}$ is becoming lower and lower. There is such a moment, that $\left(L_{A}^{*}-L_{A}^{\prime}\right)>C_{E}, L_{A}^{\prime}-L_{B}^{\prime}<0$, which means the profit under Strategy B will exceed the profit under Strategy A.

\section{References}

1. Bao, J.G.; Meng, K.; Zhang, Q.Y. Rural urbanization led by tourism. Geogr. Res. 2015, 34, 1422-1434.

2. Ryan, C.; Huang, S. The Role of Tourism in China's Transition: An Introduction. In Tourism in China: Destinations, Planning and Experiences; Ryan, C., Huang, S., Eds.; Channel View Publications: Bristol, UK, 2013.

3. Gu, H.; Ryan, C. Hungcon, China-Residents' perceptions of the impacts of tourism on a rural community: A mixed methods approach. J. China Tour. Res. 2010, 6, 216-244. [CrossRef]

4. Williams, P.W.; Ponsford, I.F. Confronting Tourism's Environmental Paradox: Transitioning for Sustainable Tourism. Futures 2009, 41, 396-404. [CrossRef]

5. United Nations World Tourism Organization. United Nations Declares 2017 as the International Year of Sustainable Tourism for Development. 2015. Available online: http://media.unwto.org/press-release/2015-12-07/united-nations-declares-2017 -international-year-sustainable-tourism-develop (accessed on 3 May 2016).

6. Manaktola, K.; Jauhari, V. Exploring consumer attitude and behavior towards green practices in the lodging industry in India. Int. J. Contemp. Hosp. Manag. 2007, 19, 364-377. [CrossRef]

7. Freestone, O.; McGoldrick, P. Motivations of an Ethical Consumer. J. Bus. Ethics 2008, 79, 445-467. [CrossRef]

8. Lim, W.M. Inside the sustainable consumption theoretical toolbox: Critical concepts for sustainability, consumption, and marketing. J. Bus. Res. 2017, 78, 69-80. [CrossRef]

9. Hall, P.A. Policy learning and policy failure in sustainable tourism governance: From first- and second-order to third-order change? J. Sustain. Tour. 2011, 19, 649-671. [CrossRef]

10. Dienhart, J. From past and present editorial board members, associate editors, and advisory editors: Anniversary reflections. Bus. Ethics Q. 2010, 20, 711.

11. Crane, A. Comments on BEQ's twentieth anniversary forum on new directions for business ethics research. Bus. Ethics Q. 2011, 21, 157-187. [CrossRef]

12. Shrivastava, P. 'Ecocentering Strategic Management', Society for Business Ethics. Environ. Chall. Bus. 2000, 2, 23-43. [CrossRef]

13. United Nations. UNEP Annual Report. 2004. Available online: https://wedocs.unep.org/handle/20.500.11822/28998 (accessed on 20 June 2020).

14. Porter, M.E.; van der Linde, C. Green and Competitive: Ending the Stalemate. Harvard Bus. Rev. 1995, 73, 120-134.

15. Leopold, A. A Sand County Almanac and Sketches Here and There; Oxford University Press: Oxford, UK, 1949.

16. Shrivastava, P.; Schumacher, G.; Wasieleski, D.; Tasic, M. Aesthetic Rationality in Organizations: Toward Developing a Sensitivity for Sustainability. J. Appl. Behav. Sci. 2017, 53, 369-411. [CrossRef]

17. Cafaro, P. Environmental virtue ethics special issue: Introduction. J. Agric. Environ. Ethics 2010, 23, 3-7. [CrossRef]

18. Shaw, B. Economics and the Environment: A "Land Ethic" Critique of Economic Policy. J. Bus. Ethics 2011, 33, 51-57. [CrossRef]

19. Yuksel, F.; Bramwell, B.; Yuksel, A. Stakeholder interviews and tourism planning at Pamukkale, Turkey. Tour. Manag. 1999, 20, 351-360. [CrossRef]

20. Eccles, G. Marketing, sustainable development and international tourism. Int. J. Contemp. Hosp. Manag. 1995, 7, 20-26. [CrossRef]

21. Sautter, E.T.; Leisen, B. Managing stakeholders: A tourism planning model. Ann. Tour. Res. 1999, 26, 312-328. [CrossRef]

22. Ryan, R.M.; Deci, E.L. An overview of self-determination theory. In Handbook of Self-Determination Research; Deci, E.L., Ryan, R.M., Eds.; University of Rochester Press: Rochester, NY, USA, 2002.

23. Font, X.; Lynes, J. Corporate Social Responsibility in tourism and hospitality. J. Sustain. Tour. 2018, 26, 1027-1042. [CrossRef]

24. Zhao, F. A study on interactions of tourism and human environment in community. J. Yunnan Univ. Financ. Econ. 2003, 19, 103-106. (In Chinese)

25. Sharpley, R. Tourism, sustainable development and the theoretical divide: 20 years on. J. Sustain. Tour. 2020, 1-15. [CrossRef]

26. Qiu, H.; Daisy, X.F.F.; Lyu, J.; Pearl, M.C.; Carson, L. Analyzing the economic sustainability of tourism development: Evidence from Hong Kong. J. Hosp. Tour. Res. 2018, 4, 226-248. [CrossRef]

27. Wei, M.; Yan, Y.Y. A study of community tourism development model based on the stakeholder perspective. Stat. Inf. Forum 2008, 23, 35-39. (In Chinese)

28. Wisconsin Historical Society. Turning Points in Wisconsin History-Travel and Tourism. Available online: https://www. wisconsinhistory.org/turningpoints/tp-048/?action=more_essay (accessed on 25 May 2020).

29. Aherne, B. Travel in retroreality. In Time, Space and the Market: Retroscapes Rising; Brown, S., Sherry, J., Eds.; M.E. Sharpe: Armonk, NY, USA, 2003.

30. Leopold, A.; Schwartz, C.W.; Leopold, A. A Sand County Almanac: With other Essays on Conservation from Round River; Oxford University Press: New York, NY, USA, 1996.

31. Shen, H.; Luo, J.; Zhao, A. The sustainable tourism development in Hong Kong: An analysis of Hong Kong residents' attitude towards mainland Chinese tourist. J. Qual. Assur. Hosp. Tour. 2017, 18, 45-68. [CrossRef]

32. Hofsted, G.; Minkov, M. Long- versus short-term orientation: New perspectives. Asia Pac. Bus. Rev. 2010, 16, 495-503. [CrossRef] 
33. Breuer, H.; Ludeke-Freund, F. Values-based network and business model innovation. Int. J. Innov. Manag. 2017, $21,1750028$. [CrossRef]

34. Kapsalis, T.A.; Kapsalis, V.C. Sustainable development and its dependence on local community behavior. Sustainability 2020, 12, 3448. [CrossRef]

35. Xu, H.; Sofield, T. Sustainability in Chinese development tourism policies. Curr. Issues Tour. 2013, 19, 1-19. [CrossRef]

36. Gibbons, L.V.; Cloutier, S.A.; Coseo, P.J.; Barakat, A. Regenerative Development as an Integrative Paradigm and Methodology for Landscape Sustainability. Sustainability 2018, 10, 1910. [CrossRef]

37. Gibbons, L.V. Regenerative-The New Sustainable? Sustainability 2020, 12, 5483. [CrossRef]

38. Sofield, T.; Li, S. Tourism governance and sustainable national development in China: A macro-level synthesis. J. Sustain. Tour. 2011, 19, 501-534. [CrossRef] 